\title{
LITERATURE CONTRIBUTION IN TEACHING OF INDONESIAN LANGUAGE AS A SECOND LANGUAGE FOR PRESCHOOL CHILDREN ${ }^{1}$
}

\author{
Sitti Rabiah $^{2}$ \\ Faculty of Letter \\ Universitas Muslim Indonesia \\ Makassar, Indonesia
}

\begin{abstract}
Teaching Indonesian language as a second language after local language is a challenge in some areas in Indonesia. Requirement for parents to teach Indonesian language to their preschool children often face barriers due to the use of colloquial language still dominated by local language. Based on the above phenomenon, the authors conducted research to find solutions to the problems faced by the preschoolers to learn the Indonesian language. Using literature review, the authors pooled the results of the study, as well as works that have been published to confirm the statement that literature have contributed to the teaching of Indonesian as a second language for preschoolers. This study found that one of the causes of lack of understanding of Indonesian language to the preschool children because reading materials tend to be difficult to understand by children. In addition, the literature is less attracted attention and interest in reading, and less considering the nature of the child who is full of imagination and curiosity. From these findings reinforce the position of a literature in order to overcome the weakness in Indonesian language teaching materials. It is now the concern of literature can be implemented well and as expected in the process of teaching the preschoolers in order to achieve maximum results.
\end{abstract}

Keywords: Literature, Teaching, Indonesian Language, Second Language, Preschool children.

\begin{abstract}
Abstrak
Pengajaran bahasa Indonesia sebagai bahasa kedua setelah bahasa daerah merupakan tantangan di beberapa wilayah di Indonesia. Keharusan bagi orang tua untuk mengajarkan bahasa Indonesia bagi anak prasekolah seringkali menghadapi hambatan dikarenakan penggunaan bahasa sehari-hari masih didominasi bahasa Daerah. Didasarkan pada fenomena di atas, maka penulis mengadakan penelitian untuk mencari solusi atas permasalahan yang dihadapi pada anak usia prasekolah untuk mempelajari bahasa Indonesia. Dengan menggunakan studi pustaka, penulis mengumpulkan hasil penelitian, maupun karya-karya yang telah dipublikasikan untuk menguatkan pernyataan penulis bahwa karya sastra memiliki kontribusi dalam pengajaran bahasa Indonesia sebagai bahasa Kedua bagi anak usia prasekolah. Penelitian ini menemukan fakta bahwa salah satu penyebab kurangnya pemahaman bahasa Indonesia anak usia prasekolah dikarenakan bahan bacaan yang cenderung sulit dipahami oleh anak. Di samping itu, bahan bacaan ini kurang memikat perhatian dan minat baca, serta kurang mempertimbangkan sifat anak yang penuh dengan daya imajinasi dan rasa ingin tahu. Dari temuan ini memperkuat posisi karya sastra dalam rangka usaha mengatasi kelemahan bahan pelajaran bahasa Indonesia. Hal yang menjadi perhatian sekarang adalah karya sastra ini dapat diimplementasikan dengan baik dan sesuai harapan dalam proses pengajarannya kepada anak usia prasekolah agar mencapai hasil yang maksimal.
\end{abstract}

Keywords: Karya Sastra, Pengajaran, Bahasa Indonesia, Bahasa Kedua, Anak Usia Prasekolah

\footnotetext{
${ }^{1}$ Presented in 4th Social, Development, and Environmental Studies International Conference 2013 'Knowledge Crossing and Social Transformation: Experiences and Challenges' organized by Universiti Kebangsaan Malaysia on March, 19th 2013 in Puri Pujangga, UKM, Bangi, Malaysia.

2 (i) https:// orcid.org/ 0000-0002-1690-0025. Corresponding author: sitti.rabiah@umi.ac.id / sittirabiah25@gmail.com
} 


\section{Introduction}

Every baby born normally, both mentally and phisically has potential capacity to learn and master any language. The Potential that brings a child to master a language gradually from the simple ability to get to the complex. The growth of children's language runs parallel to the biological and cognitive growth. However, it will grow faster depend on the environment where they living. In connection with the last statement language instruction for children preschool age can play a very important role for the growth of children's language.

One thing that is very human that every parent wants their children to always speak well and correctly in accordance with the language and cultural norms prevailing in the association of daily life. Even for Indonesian people, politeness in speaking is a nation culture which highly appreciated especially by our ancestors long ago. These indicate since long time ago Indonesian people have shown such extraordinary concern for language growth in children. Early on children has been emphasized to behave politely such as by saying a word "Tabe" when they pass in front of the parents or the elder, using the word of "kita" instead of "kamu" to the parent or a more respected to indicate their respect. The parents even threaten their children with chilly to be put in the children tongue or mouth if they found their children pronounce a dirty or rude word. They also sassy and brash the children who are speak too loud or inappropriately to the older or more respected. In such socio-cultural conditions norms rised that can be learned through expressions like "Mind your foot during walking, mind your tongue during speaking" or "Your mouth is your tiger" or "For the mouth of the body perish", and others. In short, good or bad personality can not be separated from their speech language in which good people always called "good in language culture" and in the opposite bad person always called "bad in language culture".

According to the writer, teaching of Indonesian language for preschool-age children should pay attention to the development of children's language growth that has "cultural power" as described above. Language teaching for preschool children should encourage the children to keep loving the good, the wonderful and the beauty of Indonesian language in line with socio socio-cultural norms and proper language structure. In other words, language teaching is not only emphasized the development of children's language in technical or normative language way, but also have a positive impact to the development of good character of the children.

To realize the expected language teaching as above, it is not enough to rely solely on examples of the use of formal grammatical rules but should also pay attention to the more dynamic language which can further stimulate the intellectual, imagination and creativity of the children. Literary works, which use language as a medium of expression, is properly to be utilized to realize the expectation. Why and how can it be realized? This is the key question that the author wanted to discuss further in this paper.

The discussion on the issue will be breakdown into two subjects namely: (1) the relationship between literature and the individual factors that affecting teaching of 
children in the second language, and; (2) the use of literature in the teaching of Indonesian as a second language.

\section{The relationship between literature and the individual factors that affecting teaching of children in the second language}

Implementation of language teaching as a second language for preschool children is based on awareness that: (1) the children have the potential to be able to learn and master any language: (2) the growth potential can be directed and enhanced in accordance with the level of development of biological and cognitive of the children. The first awareness will drive to the idea of what internal factors or individual factors that will determine the successful of the children in learning a second language. The second awareness will give a boost to the idea of any external factors that may affect either support or inhibit the internal factors in performing their functions for the children's learning success. In this discussion the literary define as one of the external factors such as the teaching materials that can affect the childrens's individual factors in learning the second language.

Ellis (1984) suggests that the general factors of children's individual that affect the childrens success in learning a second language are; (1) age; (2) talent; (3) cognitive style; (4) motivation; and (5) personality. The relationship of each of these factors to the literature can be described as below.

\section{a. Literature and Age}

Ellis (1984) describes the influence of age in second language teaching from three perspectives: (1) hypothesis of sensitive period; (2) cognitive perspective; and (3) effective viewpoint. Explanations of these three angles are as follows.

Hypothesis of sensitive period states that there was a time in children's language acquisition takes place naturally and without any difficulty. Penfield and Roberts (in Ellis, 1984) suggests that the peak age for language acquisition falls within the first ten years of the children's life.

According to the cognitive perspective, for children the language is a tool for expressing meaning. Halliday (in Ellis, 1984), for example, says that children respond not so much about what language it is, but for what the language it is. Rosansky (in Ellis, 1984) says that children only see similarities, less flexible thinking, and selfcentered. He also believes that children are cognitively "open" to learn the second language automatically or naturally.

Then, according to the cognitive point of view, as stated by Brown (1980) that the acquisition of a second language can be attributed to the four stages of acculturation, namely: (1) early fun and excitement; (2) culture shock, feeling separate and despised by the target culture; (3) cultural pressure, confusion and indecision in making 'reproduction'; and (4) assimilation or adaptation to a new culture. 
The above description illustrates that implementation of the second language for preschoolers need to consider the condition of the learner which among other things that: (1) they were in the peak period for language acquisition; (2) they are easily aroused to the study of language; (3) they need get pleasure and joy in learning; and (4) they are more "open" to learning a second language spontaneously and naturally.

In relation to the first point above, the teaching of a second language should provide maximum opportunities for children to know the language and diversity of its use. Literature with any variety (such as stories, conversations, or a poem) is very appropriate to be used for that purpose. Various forms of literature will provide various kinds of vocabulary diversity and its use. The importance of the use of various literary readings also in line with the Nambiar conclusion (in Sarumpaet, 1988), based on one of his research, the teaching of languages that use a variety of reading materials and learning materials are more successful than those using only one or two sources (in the same shape).

\section{b. Literature and Talent}

Based on the observations of several research experts (Genesce, 1976; Ekstrand, 1977, and Chastain, 1969), Ellis (1984) concluded among other things that the intelligence has a strong influence on the success of the acquisition of a second language, especially if the second language acquisition provides formal teaching methods, but lacking in natural second language acquisition, i.e, when knowledge of a second language is developed through learning how to communicate in the target language. Furthermore, Ellis shows also a parallel between intelligence with talent, among others, as implied in the statement of Krashen (in Ellis, 1984) that the acquisition is a subconscious in internalizing of second language knowledge, which occurs through the use of a second language naturally and spontaneously. While studying, continued Krashen, is aware of the study a second language results in the form of knowledge about the rules of the language. Krashen found that talent is only concerned with learning.

The signal can be captured from the illustration above, among others, that individual differences in children in the form of talent and intelligence will be felt in the process of learning a second language that uses materials and formal methods, but the difference will not be too felt when the learning process is developed in the form of learning natural communication. Thus, it can also be concluded that in this study a group or per-class suitable material that can engage children in activities naturally communicate in the target language.

If the above conclusions can be accepted, the literary works, such as stories, conversational, "role playing", or "oral interpretation" and others, have a great stock for it. The observations of van Klinken (1991) on the kindergartens and elementary schools around Salatiga (Central Java) suggests that one of the causes of the failure of Indonesian students studying in these schools are reading materials that are difficult to understand because of the language used in the literature is not their everyday language 
(in Purwo, 1993). Results of van Klinken interviews to the teachers indicate that "the children is only able to imitate the teacher's sentence, but did not dare use the Indonesian language in front of the class, in front of their friends.". Once again, literature, when teachers use in clever and creative way, has very significant role in order to address and anticipate the teaching of Indonesian language that for the time being not encouraging.

\section{c. Literature and Cognitive Style}

Cognitive style is a term used to refer to the way of people used to receive, conceptualize, organize, and reply to the information they recieve (Ellis, 1984). According to Ellis, the various dimensions of cognitive style have been identified; it is generally presented as a dichotomy. Dichotomy mentioned by Ellis is the style of "bound field" (field deference) and the "free field" (field independence). One interesting thing is that according to Ellis deference field greatly facilitate the acquisition of a second language naturally, but indefendence field will be more successful in learning in the classroom.

What is stated above is emphasized talent issues in relation to second language teaching discussed earlier. The relationship with literature is quite clear, that if only a language explanations and examples of grammatical tend to be difficult to apply in the field dependence power and just better suited in the style independence field, so that the literature can be applied to both, depending on the cleverness of the teachers to choose the type and variety of literature that fits with his or her style.

\section{d. Literature and Motivation}

Based on the analysis of the number of research results reported by experts, Ellis (1984) concluded that motivation depends on the goal of student learning is more accountable to influence the motivation to learn a language than simply derived from academic or communicative success. In such cases, according to Ellis, motivation can be developed with a careful selection of learning activities, both to achieve a high level by providing opportunities for students to be creative for the sake of success and intrinsic willingness to help.

Relevant to the Ellis statement above, the observation of van Klinken (in Purwo, 1993 ) to the Indonesian language teaching in primary schools such as kindergarten and Play Group in the villages around Salatiga (Central Java) reveals that the literature used are not inviting children in such a way that they are interested in reading it. Reading materials were observed by van Klinken shows that text writers more interested in vocabulary expansion and language structures rather than the presentation of the content that can be captivate by the children. According to a teacher who was interviewed by van Klinken, "children are more interested in reading textbooks Social Science and History books than Indonesian." Why such thing happened? Van Klinken reveal the 
answer that the social studies and history books is the "story book ", while the Indonesian language teaching book is a textbook alone.

What can we believe from the above description that the literary work, especially the "story", it is appropriate to be used in language teaching in order to motivate students to learn language? The daily life shows that children love listening to stories. They will beg to read or tell the umpteenth time, if the reader or narrator accidentally omits part of the story or any of the name or the other, then they will immediately correct the error by any genuine concern. Gazden (in Sarumpaet, 1988) state that reading stories that can stimulate conversation and children should be given the widest possible opportunity to discuss ideas openly and the story book is very suit to create a conversation about the illustrations and the story. Cullinan et al (in Sarumpaet, 1988) also argues that literature extends the language capabilities and they proposed that the introduction of children to literature should be started in the early age.

\section{e. Literature and Personality}

One of the interesting hypotheses have been examined on the personality factor is that students who has open personality (extrovert) will be faster and more successful in learning a second language than those that are closed personality (introvert). One reason is as stated by Ellis (1984) that students who have open personality will be easier to get along with the other second language users, and therefore it will be more accepting input. In this regard, the literature can be utilized such as in the form of "roleplaying", "creative drama". "Oral interpretation" or "choral speaking" can be used to overcome the psychological barriers experience by students who have closed personality.

Ellis (1984) based on the findings or results of study wrote by Rubin (1975) and Naiman et al. (1978), submits a detailed characteristics (personality). Students which good in language has a character as follows:

1. Able to respond to the dynamics of group learning situations to avoid anxiety and able to restraint not to respond to the negative situation;

2. Looking for a chance / opportunity to use the target language;

3. Using the maximum opportunity to practice listening and responding to hold a second language speech directed at oneself or others with emphasis on meaning rather than form;

4. Adding learning activities through direct contact with speakers of a second language;

5. Act like teenagers or adults rather than as children;

6. Having analytical skills sufficient to receive, catagorize, and store the linguistic characteristics of the second language;

7. Has a strong incentive to learn a second language (which describes the integrative or instrumental motivation) and also developed the "task motivation" (ie respond positively to the selected or given task); 
8. Being able to adapt the vary of learning conditions.

How language teaching can form student personality like described above? the first thing is certain is that it can not be realized if only relying purely to the grammatical teaching materials. Therefore, it needs to be supported with adequate teaching materials containing emotion, life dynamic, tones and atmosphere. The eligible materials for such purpose are literature. The remaining problem now is the ability of teachers to utilize a wide range of literature to optimize student learning performance in the schools. It is the last issue that going to be discussed further.

\section{Reflection of Indonesian Language Teaching for Preschool Children}

Admitting oneself weaknesses is one of the toughest tasks in the era where people starve of "recognition" as it is today. In fact, whether consciously or not, many who have chosen and are being fought in the shortcut to "prefer forge advantages rather than admit shortcomings. "Fortunately, the scientific principle very opposed to it, so no one reluctance to admit that the Indonesian language teaching of preschool-age children are still likely, fueled by the mistaken assumption (ie the assumption that at the time to enter elementary school or kindergarten all childrens throughout Indonesia should have proviciency of spoken Indonesian language skill, so the rest to do just learn to develop writing skill). The results of research by experts, such as finding of Sommerset (in Purwo, 1993) about one of the reason why a number of children in elementary school or kindergarten stuck in the low-grade classroom assumed caused by lack of mastery of the Indonesian language. As van Klinken (in Purwo, 1993) also found that the high rate of repetition and drop out of school at the beginning of grade school was most likely caused by the transition from first languages into Indonesian language that run not smooth support the suspicion that the error assumption has a negative impact on the teaching of Indonesian for preschool children in Indonesia.

As discussed earlier there was an indication that one cause of the increasingly intensified the negative impact is likely to be difficult reading material that is understood by the students, who are less attractive, discourage students' interest in reading contest, lack of consideration to the nature of the children who are full of imagination and curiousity. The earlier discussion, however, also gave assurance that the literary work has a big stake in order to overcome the weakness of Indonesian teaching materials. The remain issue that need to be discussed is how to utilize the literature to optimize the success of Indonesian language teaching for preschool children as expected to be exist in today schools teaching.

\section{Conclusion}

From the above discussion, it can be concluded that the children's individual factors are strongly associated with literary elements such as: 1) literature and life; 2) literature and talent; 3) literature and cognitive styles; 4) literature and motivation; and 
5) literature and personalities play an important role for the success of children in learning of Indonesian language as a second language for preschoolers.

After finding the fact that the literature contributed significantly to the teaching of Indonesian language, then literature should get more attention. In addition, implementation in the field is also very important to allow the expected results can be achieved in the teaching process of the preschoolers.

\section{References}

Alwi, Hasan. 1998. Tata Bahasa Baku Bahasa Indonesia. Jakarta: Balai Pustaka.

Brewer, Elizabeth, dan Hartley. 2005. Raising Happy Kids. Yogyakarta: Inspirasi Buku Utama.

Bunanta, Murti. 2004. Buku, Mendongeng, dan Minat Baca. Jakarta: Pustaka Tangga.

D. Gunarsa, Singgih. 1987. Dasar dan Teori Perkembangan Anak. Jakarta: BPK Gunung Mulia.

Djajasduarma, Fatimah T. 1993. Metode Linguistik. Bandung: Eresco.

Guntur Tarigan, Henry G. 1995. Dasar-Dasar Psikosastra. Bandung: Angkasa.

Hainstock, Elizabeth G. 1999. Metode Pengajaran Montessori. Jakarta: Pustaka Dela Prasa.

Jamaluddin, Mahfuzaah M. 2001. Psikologi Anak dan Remaja Muslim. Jakarta: Pustaka Al-Kautsar.

Kutha Ratna, Nyoman. 2004. Teori, Metode, dan Teknik Peneliti Sastra. Yogyakarta: Pustaka Pelajar.

Kridalaksana, Harimurti. 1983. Kamus Linguistik. Jakarta: Gramedia.

Megawangi, Ratna. 2004. Pendidikan Holistik. Bogor: IHF.

Parawansa, Paturungi. 1990. Pendekatan Konstratif Linguistik dalam Pengajaran Bahasa Indonesia. Ujung Pandang: FKIP UNM.

Rabiah, Sitti. 2002. Analisa Tema, Topik, dan Judul dalam Cerita Anak Ketika Ramadhan Tiba. Makassar: Pascasarjana Universitas Hasanuddin.

Sylvia, Rim. 1997. Why Bright Kids Get Poor Grades. Jakarta: Gramedia Widia Sarana Indonesia. 